\title{
El crimen, la imagen de Colombia y la interpretación del presente en los cuentos de Germán Espinosa
}

\author{
Orlando Araújo Fontalvo \\ Universidad de Norte
}

Título: El crimen, la imagen de Colombia y la interpretación del presente en los cuentos de Germán Espinosa.

Resumen: El crimen es una de las temáticas más significativas en la cuentística de Germán Espinosa. Para comprender la naturaleza de esta recurrencia hay que revisar cuidadosamente las breves ficciones en donde lo criminal se manifiesta con una fuerza inatajable, con un impulso sin tregua ni respiro, poniendo de manifiesto una sociedad anómica en su tejido más hondo y descarnado.

Palabras clave: Germán Espinosa, Crimen, Anomia, Cuento, Catolicismo.

Fecha de recepción: 11/12/2019.

Fecha de aceptación: 20/12/2019.
Title: The Crime, the Image of Colombia and the Interpretation of the Present in the Germán Espinosa's Tales.

Abstract: Crime is one of the most significant topics in the short-stories of the writer Germán Espinosa. In order to comprehend the nature of this recurrence it is necessary to cautiously revise the short fictions in which the criminal aspect manifests itself as an unassailable force, with an impulse without respite nor rest, revealing an anomic society at its deepest and darkest.

Key words: Germán Espinosa, Crime, Anomie, Short-story, Catholicism.

Date of Receipt: 11/12/2019.

Date of Approval: 20/12/2019. 
En Colombia, muchos alientan esperanzas sobre un porvenir más luminoso y justo. Yo, no. Si ese porvenir va a existir algún día, se necesitan largas décadas para que se realice. En nuestro país, los instantes de respiro han sido siempre un relámpago fugaz en mitad de una borrasca.

Germán Espinosa

La cura a la que Cronos nos somete llega tarde o temprano; lo difícil es saber cuánto se necesitará para que los golpes de la Historia maduren a una república acostumbrada a que la presida la muerte.

Rodolfo Ramón De Roux

Desde Émile Durkheim (1858-1917) —esto lo saben bien no solo los sociólogos, sino principalmente los estudiosos de la criminología moderna-, el crimen se percibe no como un hecho biológico, sicológico o patológico, sino, sobre todo, como un fenómeno natural, propio de toda estructura social. El crimen, el delito, la desviación ocurren en todas las sociedades, sin que importe el clima o la raza, tanto en momentos de crisis y escasez como en los instantes de mayor prosperidad. Sin embargo, a juicio de Alessandro Baratta, cuando se han

sobrepasado ciertos límites, el fenómeno de la desviación es negativo para la existencia y el desarrollo de la estructura social, si se acompaña de un estado de desorganización, en el cual todo el sistema de reglas de conducta pierde valor, mientras no se haya afirmado aún un nuevo sistema ${ }^{1}$.

Para Germán Espinosa, buena parte del influjo violento de la sociedad colombiana se debe a la fuerte represión sexual que adelantó la Iglesia Católica a través de múltiples prácticas e instrumentos. Aunque sin duda se queda corto en cuanto a las variables que explican la violencia colombiana, la idea de una sociedad constreñida para el amor que desemboca de

1 Alessandro Baratta, Criminología critica y crítica del derecho penal. Introducción a la sociologia jurídico-penal, México, Siglo XXI, p. 56. 
modo indefectible en la muerte y el crimen, persiguió al escritor cartagenero a lo largo de su vida. Para algunos, esta idea puede resultar excesiva, pero lo cierto es que son muchos los cuentos en donde la presencia del crimen y la anomia está definida de una u otra forma por un sustrato religioso, católico, para ser más preciso.

El tema del crimen en los cuentos del cartagenero es producto de la misma idea acerca de la represión sexual de la que también se desprende la temática del erotismo. Una vez más, las pulsiones del amor y de la muerte tienen un nacimiento común. Muchos de los cuentos de Espinosa surgen, como se ha venido señalando, de su conflictiva relación con el catolicismo, y no debe olvidarse, pues resulta de la mayor importancia, que las religiones son ante todo el corolario político de las creencias en el más allá. De modo que no se trata de la simple adscripción a un sistema de creencias, sino que es una cuestión fundamental en el ámbito social, político, económico e ideológico, que supone un hondo cuestionamiento al proyecto que un determinado grupo dominante ha logrado imponer en la sociedad colombiana tanto en lo espiritual como en lo material.

Así, es necesario comprender los alcances y las implicaciones del crimen como productor de sentido, como imagen recurrente que atraviesa la narrativa breve de Espinosa y permite desentrañar algunas de las más significativas características de su propuesta estética e ideológica. De manera complementaria, el concepto de anomia, introducido por Emile Durkheim y desarrollado posteriormente por Robert K. Merton ${ }^{2}$, será entendido en el marco del presente artículo en los términos en que lo plantea Peter Waldmann, esto es, como "un estado de la sociedad que se caracteriza por la ausencia de una estructura normativa consistente y obligatoria" ${ }^{\text {. }}$.

¿Pero cuál es el papel de la Iglesia en todo esto? ¿Qué tiene que ver el catolicismo con el crimen y la anomia que padece la sociedad colombiana? ¿No es acaso un despropósito de Germán Espinosa responsabilizarla de traicionar las ideas de Cristo y engendrar el odio y la muerte a través

2 Uno de los sociólogos norteamericanos contemporáneos más destacados. Incorporó la teoría de la anomia de Durkheim a una teoría general del comportamiento desviado.

3 Peter Waldmann, Guerra civil, terrorismo y anomia social. El caso colombiano en un contexto globalizado. Bogotá, Norma, 2007, p. 101. 
de la represión sexual o el Santo Oficio de la Inquisición? ¿Acaso el mismo autor no reconoció varias veces los aspectos positivos de la prédica del amor contenida en los evangelios?

Sobre estos y otros interrogantes, los escritos del profesor Rodolfo de Roux arrojan sin duda muchas luces. En sus estudios eclesiales analiza lúcidamente sus actitudes y posiciones históricas, mostrando con toda precisión cómo desde el mal llamado Descubrimiento, la Iglesia Católica ha estado echando mano de la violencia para cuidar sus intereses en América. En algunas ocasiones, con instrumentos explícitos de violencia física, y en otras, con refinados artilugios de violencia simbólica. Ciertamente, "espada, cruz e intolerancia nos acompañan desde los albores de aquello que llaman nuestra nacionalidad"4.

Por otra parte, es un hecho probado que en Colombia fue la mano de la Iglesia la que movió los hilos de las sangrientas guerras entre liberales y conservadores. Disputas que han pasado a la historia como grandes conflictos políticos e ideológicos, pero que no pocos califican simplemente como guerras religiosas. En realidad, apenas si había diferencias superficiales en la visión del Estado que tenían los dos bandos enfrentados. La cuestión de fondo, la diferencia irreconciliable no era otra que el papel de la Iglesia en la vida de la nación. Los conservadores fueron los defensores de los privilegios y poderes eclesiásticos. A su vez, los liberales marcharon a la guerra, de la que saldrían derrotados, para intentar recortar los inmensos poderes concedidos a la Iglesia. El paso de la antigua Nación Católica a la república multiétnica y pluricultural consignada en la constitución de 1991 ha sido el resultado de una dilatada dinámica de sangre que está todavía muy lejos de consolidarse, esto es, de dar el salto del papel a la realidad.

Lo que antecede no es un simple recuento anecdótico, pues resulta fundamental para poner en contexto y comprender la idea de Germán Espinosa en cuanto a la responsabilidad histórica del catolicismo en los orígenes de la violencia nacional. Una idea complementaria se recoge en uno de los más completos análisis que se han escrito sobre el asunto:

Llama la atención que las guerras civiles colombianas del siglo XIX, que, al menos desde el punto de vista de su retórica, eran similares

4 Rodolfo Ramón De Roux, "El inquisidor que todos llevamos dentro”, Revista Huellas, 25 (1989), pp. 22-29 (p. 28). 
a las guerras religiosas europeas del siglo XVI, a diferencia de estas, no produjeron una fuerza dedicada únicamente al estado y el bien común. Más bien, profundizaron y perpetuaron la dicotomía amigo-enemigo, hasta que esta finalmente se volvió un bien mental común de todas las capas sociales 5 .

La destrucción del enemigo es una de las claves fundamentales para comprender los complejos esquemas de pensamiento que estimulan y favorecen el crimen y la violencia en Colombia. La expresión, ligada inicialmente a los partidos en contienda y, por ende, a la Iglesia Católica, se filtró a través del tiempo a todas las capas sociales, instalándose en la conciencia colectiva, el mundo de la vida y las ideas de millones de colombianos. ¿Y cómo combatir una manera de pensar que ha penetrado tan profundamente en el imaginario y el discurso social en todos los niveles del país? Como afirma Waldmann,
no hay ciudad, región ni pueblo en el cual no exista una íntima ene- mistad entre dos o tres actores principales, sean individuos, clanes familiares o asociaciones organizadas que determinan la vida social y obligan a los demás actores a tomar posición y enfilarse ${ }^{6}$.

Germán Espinosa siempre tuvo claro que, en una sociedad más libre para el amor, más abierta a la tolerancia, habría siempre menos espacio para la pulsión del crimen y la cultura de la muerte. El amor y la tolerancia, bienes comunes de los cristianos de la iglesia primitiva que todavía observaba las enseñanzas de Cristo y daba a los demás lo mismo que deseaba recibir; iglesia primigenia cuyo rostro amoroso y caritativo comenzó a desdibujarse a partir del siglo IV cuando sus jerarcas decidieron, en mala hora, establecer alianzas no propiamente santas con los señores de este mundo. 


\section{El Crimen en los Cuentos de Germán Espinosa}

Este proceder de doble fondo ha sido mejor captado en novelas que en análisis sociológicos.

Peter Waldmann

En uno de sus primeros cuentos, En casa ha muerto un negro (1961) ${ }^{7}$, Germán Espinosa cuenta la historia de una pareja de tunjanos sospechosos de haber asesinado a uno de sus trabajadores. Se trata, como el mismo autor reconoce, de "un cuento influido de la primera a la última línea por

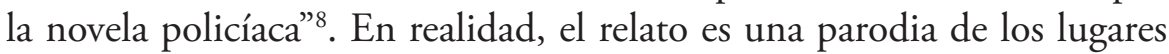
comunes que caracterizan al género. Los esposos implicados, el negro asesinado a cuchillo, tendido aún en el piso, y el investigador que es llamado para esclarecer los hechos. No obstante, el autor decide conectase con la tradición dándole un giro inesperado a varios de los aspectos definitivos de la trama.

En primer lugar, no hay enigma que resolver. Es evidente que el crimen fue cometido por uno de los esposos, pues, según afirma el juez que investiga el caso, nadie más vive en un perímetro de varios kilómetros. Si acaso hay algo que aclarar son los móviles del asesino. En segundo lugar, el juez municipal Alcides Tribiño no está interesado en el crimen de un negro. Considera que los esposos son un par de estúpidos por haberlo llamado, cuando "bien pudieron sepultarlo en el potrero y decir luego que había desaparecido" ". Hay una flagrante contradicción e impostura entre el rigor jurídico que encarna el juez y el estado de anomia que revelan sus palabras.

En el fondo, Alcides Tribiño tenía mucho que reprocharle al Estado colombiano. ¿Por qué obligaba a un juez municipal, como él, a asumir las funciones de cualquier juez de instrucción, en cambio

7 Este cuento, que debió publicarse en La noche de la Trapa (1965), se extravió y solo vino a ser publicado en la colección Los doce infiernos (1976).

8 Germán Espinosa, Cuentos completos, Alfaguara, Bogotá, 2007, pp. 127-128.

9 Germán Espinosa, ibidem, p. 131. 
de proveer los dos cargos como lo mandan las buenas costumbres? Le repugnaba todo este asunto y, para ser sincero consigo mismo, lo tenía impresionado la presencia, a pocos centímetros suyos, del cuerpo del delito ${ }^{10}$.

En realidad, a Tribiño lo que le interesa es "evitarse el ajetreo de las diligencias" 11 . Le tiene sin cuidado la suerte del negro apuñalado por la espalda con un cuchillo de cocina. Lo que quiere es salir cuanto antes de esa engorrosa situación en la que lo metió el matrimonio. Hay en el joven de veintitrés años que escribe esta historia una crítica contundente al sistema judicial colombiano. El cuento, por otra parte, es la historia de la malhadada pareja formada por Iván Bocarejo y la rubia Leonor Radzynovich. Una criatura sensual, atrapada entre los prejuicios raciales de su abuelo judío y la educación sexual represiva de su madre católica.

Desde muy pequeña - Leonor habló con voz reposada y un poco contrita- aprendí a temerles a los indios y negros. A los unos por ladinos y a los otros por obscenos. Mi madre decía que los negros eran violadores de niñas y que nińa violada por negro jamás llegaría a desarrollarse ni a ser mujer ${ }^{12}$.

En el trasfondo de sus palabras, se aprecia con claridad todo el discurso que construyó la Iglesia para legitimar la Conquista de América. Discurso de descalificación del otro, cuyo propósito esencial consistió en justificar lo injustificable: nada menos que el exterminio y la esclavitud. Por si fuera poco, la mujer confiesa además que una amiga, cuyo padre era afín a la esclavitud, le aseguraba que los negros "no tienen alma, que son como animales"13. En su larga confesión, que no aprueba el marido, reconoce que a los diecinueve años llegó a la alcoba nupcial con la cabeza tan llena de ideas retorcidas sobre la sexualidad que no podía sentir otra cosa que odio hacia el hombre con quien "tenía que cumplir la obligación matrimonial. Tener hijos..."14.

10 Germán Espinosa, ibidem, p. 130.

11 Germán Espinosa, ibidem, p. 131.

12 Germán Espinosa, ibidem, p. 137.

13 Germán Espinosa, ibidem, p. 137.

14 Germán Espinosa, ibidem, p. 138. 
Leonor, cuyo nombre es sin duda un homenaje a Poe, confiesa su culpa delante del marido, que todo el tiempo ha tratado de protegerla, revelándole al inepto investigador la naturaleza pasional del crimen:

\begin{abstract}
Cuando una mañana, mientras tú hablabas a los aparceros, encontré al negro en la cuadra, la tentación fue superior a mí. Él cantaba una música triste y la acompañaba con suaves golpes sobre las tablas de la caballeriza. Creo que fue el vaho de las bestias, el perfume del estiércol... Lo gocé sobre el heno, en una especie de delirio legendario, una suerte de acercamiento a los orígenes mismos de la vida, de la que yo me sabía apartada y repudiada. Tengo que confesarlo, fue algo... completamente distinto. Su piel negra, su condición inferior, no dejaban lugar a dudas ${ }^{15}$.
\end{abstract}

Es una escena completamente anómica, donde no se sabe quién es más culpable: si la esposa, por adúltera y asesina; el esposo, por complicidad al tratar de encubrir a la mujer; el negro, por la supuesta condición de chantajista que le atribuye el juez Tribiño; o el mismo investigador, que ante la confesión de la mujer, burla cualquier atisbo de justicia y echa por tierra la sanción al pedirle al marido que lo ayude a cavar una fosa para enterrar el cuerpo en el potrero, y finalmente coger el teléfono e informar con irritante cinismo que todo ha sido una broma de algún desocupado y que en esa casa no ha muerto ningún negro. El cierre, con Tribiño al teléfono dando una versión falsa de los hechos, conecta a su vez el cuento del joven Espinosa con Emma Zunz, una de las ficciones memorables del maestro argentino Jorge Luis Borges.

De manera análoga, en Ius in se ipsum $(1964)^{16}$ Espinosa continúa desarrollando y afinando su particular estética del crimen. Este nuevo acercamiento, narra la forma audaz en la que Isidro Galanzó planea y ejecuta su propia muerte, de manera tal que su necio amigo Darío Uriburru sea atrapado en flagrancia. La trama discurre en medio de la fría noche bogotana. La Avenida Caracas y el tradicional barrio de Teusaquillo sirven de marco para este cuento en donde, de nuevo como en Emma Zunz, se pone

15 Germán Espinosa, ibidem, p. 139.

16 Expresión que hace referencia a una antigua doctrina jurídica que defendía los derechos naturales y esenciales que una persona tenía sobre sí misma. 
a prueba el concepto de verdad. Es la historia de una venganza. Galanzó desea castigar al presuntuoso abogado Uriburru. No tolera su soberbia, "la siempre desafiante sonrisa de su dentadura acrílica, con su tono de superioridad, con sus prácticas yogas para liberar al yo de su sujeción al mundo exterior, con sus pequeñas argucias y estratagemas jurídicas" ${ }^{17}$.

El relato puede ser leído a varios niveles, atendiendo a la tesis según la cual todo cuento narra dos historias. Una de ellos recrea las peripecias de un individuo que decide quitarse la vida por despecho. La anomia aflora cuando resuelve que su suicidio debe transustanciarse en homicidio para que, de este modo, sea castigado el sujeto que se atrevió a estimular a su mujer para que lo abandonara. En la mente del criminal, su autoeliminación supondrá un castigo por partida doble, pues Marlene se sentirá culpable y el jurista será procesado y condenado por el mismo sistema que representa.

Pero la breve ficción de Germán Espinosa desarrolla asimismo la historia de un enfrentamiento religioso. Está claro que Darío Uriburru alardea perversamente de su condición de yogui, al punto de menospreciar a Galanzó y recomendarle la muerte:

El solo pensamiento en el suicidio denota un desequilibrio, una profunda desarmonía, una instilación tal de la maldad en nuestro espíritu, que el propio organismo propende a la muerte. - Gesticulaba para hacer fulgir los cambiantes espejos de piedra en sus engastes indostánicos.... Hazlo, no vaciles. Te lo digo yo, que rindo culto al equilibrio y a la luz, que domino por el espíritu todas las funciones psíquicas y fisiológicas. Yo, a quien nada, ni esos pensamientos; a quien nadie podría dañar, porque estoy compenetrado con la armonía del mundo. Créelo; sólo los indestructibles merecemos vivir ${ }^{18}$.

Este hilo narrativo desemboca a todas luces en la ironía. A su vez, la condición católica de Isidro Galanzó se hace manifiesta en su nombre, sacado del santoral, pero sobre todo en la referencia que se le escapa al suicida de "las exégesis canónicas"19, el método paradigmático de la hermenéutica cristológica. En este sentido, no constituye una exageración afirmar que Ius in se ipsum transgrede con agudeza el sistema jurídico colombiano,

17 Germán Espinosa, Cuentos completos, p. 81.

18 Germán Espinosa, ibidem, p. 83.

19 Germán Espinosa, ibidem, p. 81. 
vinculando asimismo el crimen y la anomia al método de lectura e interpretación de los textos bíblicos.

Un año después, lo criminal resurgirá con mucha fuerza en la cuentística de Espinosa. Paladines (1965) cuenta la historia de un intelectual, un hombre de letras, un profesor de filosofía que es llevado a prisión por denunciar la corrupción y la anomia en la que se encuentra sumida la sociedad a causa de una suerte de dictador que la oprime. El cuento es narrado, al parecer, por la propia conciencia del recluso.

No, no debías ser tan duro contigo. A la postre, si estabas recluido en este penal, justamente ello se debía a haberte sostenido en tus trece mientras tus colegas, uno tras otro, daban el brazo a torcer sin remedio frente al dictador, para acabar convirtiéndose, en el peor de los casos, en sus áulicos y validos. Muy pocos optaron, a lo sumo, por callarse la boca o escribir, en lo sucesivo, sobre horticultura o sobre fisión del átomo o sobre Hölderlin o sobre Descartes. Tú, en cambio, sin apartarte de tu línea, continuaste denunciando, entronizaste tu protesta, primero en la columna y, cuando el periódico engrosó también las huestes turiferarias del Jefe Supremo, en hojas volantes ${ }^{20}$.

Este personaje culto, que sabe de filosofía y conoce la poesía de César Vallejo, valiente e incorruptible columnista, es reducido a prisión justamente por hallarse al margen de un sistema que ha sido puesto de rodillas por uno de esos tenebrosos caudillos mesiánicos que se hacen con todo el poder enarbolando banderas de libertad y reivindicación social. Lo cierto es que está en la cárcel. Es lo que podría llamarse eufemísticamente "un preso político". Pero en ese sistema anómico, la cárcel en lugar de ser un espacio para la rehabilitación de los individuos, para su resocialización, se convierte en un ámbito de tortura sicológica que terminará por convertir al pulcro hombre de letras en un oscuro criminal.

El alcalde en persona visita con frecuencia al profesor para decirle que su esposa lo traiciona mientras él está en la cárcel por defender sus nobles ideales: "Es verdaderamente cochino. Reemplazarlo a usted, un carajo de letras, por cualquier badulaque hijo de la gran puta" ${ }^{21}$. El cuento juega

20 Germán Espinosa, ibidem, p. 208.

21 Germán Espinosa, ibidem, p. 209. 
con la plurisignificación, no cierra ninguna puerta. La voz de la conciencia evalúa todas las posibilidades, duda y se cuestiona permanentemente. Al principio el profesor no cree una palabra, pero los guardianes y el personal de la prisión se dan a la tarea de alimentar las dudas y el suplicio.

Un día la mujer del columnista deja de visitarlo, lo que acrecienta sus dudas y lo sume en una profunda crisis. "Los carceleros redoblaron sus hablillas, enredándolas cada vez más. Tú, el profesor burlado, impotente; y ella, en manos de algún vividor" ${ }^{22}$. A los dos meses, el mecanismo de tortura da un giro estratégico aumentando la intensidad del padecimiento: le es asignado al profesor un compañero de celda. Un hombre que resulta ser su propia antítesis, que le habla con orgullo "de lo bello que es ejercitar la equitación en compañía de ciertas amazonas sensiblemente frívolas"23, que le escupe en la cara, como sin intención, que "ningún ideal vale lo que una mujer bien montada, ¿oye? Los ideales se hicieron para los maricas" 24 . Cómo era de esperar, no pasará mucho tiempo para que uno de los carceleros propine el pérfido golpe y empuje al atormentado profesor a los abismos del crimen: "Mire lo que es la casualidad. Y le ha tocado por compañero el mismo que le robó la mujer" 25 .

“¿Pero no será un ardid, una macabra comedia montada por los esbirros del dictador?" 26 , se pregunta la conciencia antes de que el profesor descargue el garrotazo en la cabeza del hombre dormido. "Acaso Ruth ha estado a pocos metros, ansiando verte, y no se lo han permitido" 27 . No se sabrá nunca, es un dato escondido completamente elíptico. Lo único cierto es que el profesor, que entró a la cárcel como un ejemplo de rectitud, se quedará recluido en prisión a causa de su conducta criminal. $\mathrm{O}$ quizá mucho peor, como intuye la propia conciencia:

Todo ello lo traes a la memoria ahora, porque tienes que cobrar valor para asestar el golpe. Mas, ¿no podría tratarse, tan sólo, de una trampa, de una manera de hacer peor tu suplicio? No puedes, no

22 Germán Espinosa, ibidem, p. 211.

23 Germán Espinosa, ibidem, p. 211.

24 Germán Espinosa, ibidem, p. 212.

25 Germán Espinosa, ibidem, p. 212.

26 Germán Espinosa, ibidem, p. 212.

27 Germán Espinosa, ibidem, p. 212. 
debes perder de vista esa posibilidad. Vas a convertirte en un asesino y eso no es lo peor. Lo peor será que estos carceleros te matarán a palos cuando vengan por la madrugada y vean el cráneo hecho masilla, el hombre tendido allí sin respirar. Será atroz, lo sabes. No posees la necesaria fuerza de carácter para resistirlo ${ }^{28}$.

En este breve cuento, Germán Espinosa logra mostrar cómo la tiranía, valiéndose de toda clase de artimañas, consigue socavar los cimientos morales de la oposición, encarnada en el profesor de filosofía, al tiempo que tergiversa los preceptos del derecho y de la axiología misma, transformando a su único oponente en un criminal al que es necesario reducir al calabozo y finalmente matar a palos como a un perro rabioso. Es decir, todo un derroche de anomía en su más pura expresión y, una vez más, la idea perversa de la destrucción física y moral del enemigo.

Como puede apreciarse, son muchos los relatos en donde Germán Espinosa ataca lanza en ristre contra lo que algún político colombiano llamó el Régimen. Ese estado de desarreglo esencial, de contradicción estructural, que caracteriza a la sociedad colombiana. El comportamiento delictivo se convierte, así, en un valioso instrumento que incorpora el autor cartagenero a su proyecto estético para rastrear los orígenes y las dimensiones de la anomia en un país históricamente obsesionado con las leyes. La anomia colombiana que recrea Espinosa en sus relatos evoca, más bien, "un estado de la sociedad en el cual las leyes han dejado de regir, de modo que cada quien persigue sus propios intereses y fija sus propias reglas" 29 .

En Confesión de parte (1979), escrito en Belgrado y construido enteramente a partir de la técnica del dato escondido en hipérbaton, se ve, por ejemplo, como una mujer teje una sofisticada red pasional para cazar a Antonio Cocuy, el asesino de su hermano. El cuento, como La tejedora de coronas, es narrado desde la perspectiva femenina. A través de la confesión de la mujer, podemos advertir la manera vergonzosa en que las autoridades encubren el asesinato del hermano, dejándola sin otra alternativa que la venganza por su propia mano.

28 Germán Espinosa, ibidem, p. 209.

29 Peter Waldmann, op. cit., p. 106. 
Yo era sólo aquella niña de ocho años, pero no puedo olvidar la palidez y el temblor de mi cuñada, la viuda virginal, ya extraviada en la entrerrealidad de su locura, relatando compulsivamente de qué manera Antonio Cocuy se valió de la amistad del alcalde, de quien era guardaespaldas, para lavar con ese crimen el honor de su hermana y huir después por entre las timbas de la noche, mientras las propias autoridades municipales se encargaban de borrar toda pista o vestigio de su culpa ${ }^{30}$.

Por regla general, cuando la justicia no opera, cuando las violaciones a las normas no son sancionadas, se abre paso la venganza, que alimenta la anomia y la criminalidad. La complicidad de las autoridades al encubrir un crimen, lo único que produce es un nuevo crimen. Por ello la confesa, sin dejar que se consume su noche de bodas con el asesino de su hermano, apenas este amaga con ejecutar el "sagrado crimen" para el que su madre la había preparado toda la vida, le rebana la carótida con una hoja de afeitar. "Para que sintiera lo que sintió Joaquín cuando él, Antonio Cocuy, lo cosió a balas aquella noche de julio entre los brazos de su desposada" ${ }^{31}$. Con el título mismo y la expresión "sagrado crimen" 32 , el autor consigue vincular una vez más la represión sexual, el catolicismo y la criminalidad.

Otra interesante manifestación de comportamiento homicida se halla en El primo del difunto (1983), donde el estudiante Teofrasto Narváez cae abatido a puñal por el intocable hijo de un terrateniente, "reconocido matón que había hecho ya varias degollinas de indios mocoas en Sibundoy" 33 . El estudiante es zambo, o sea, la mezcla de sangre negra e indígena, y su nombre, que alude al sucesor de Aristóteles en el Liceo, lo convierte en un personaje profundamente simbólico en la lógica interna del relato. Sin embargo, como resultado de la intimidación que ejerce el señor feudal que legitima las acciones del hijo, nadie está dispuesto a testificar, nadie espera nada de la justicia. El padre del pintor Augusto Rivera, testigo de excepción, le hace saber a su hijo que si no huye de inmediato, será llamado a declarar y, como es bien sabido, "no es bueno testificar

30 Germán Espinosa, Cuentos completos, p. 308.

31 Germán Espinosa, ibidem, p. 309.

32 Germán Espinosa, ibidem, p. 309.

33 Germán Espinosa, ibidem, p. 300. 
contra uno de los hijos del amo de la región" ${ }^{34}$.

El cuento breve de Germán Espinosa, destinatario de la narración del pintor Rivera, compendia una serie de gravísimas anomalías, comunes a vastas extensiones del territorio nacional en donde los poderosos dueños de la tierra se han puesto por encima de la ley, pudiendo cometer toda suerte de atrocidades sin que nadie se atreva a denunciarlos. En la ficción del cartagenero, el pintor Rivera es convencido a medio camino por el primo de Teofrasto para que regrese a testificar y no permita que quede impune "aquel crimen abominable, cuya víctima había sido, para mayor desdicha, uno de los mejores estudiantes del liceo" 35 . Cumpliendo con la palabra empeñada y un poco avergonzado de su inicial cobardía, el pintor Augusto Rivera, para asombro de los mismos familiares del difunto, regresa al pueblo, testifica en el juicio y descubre finalmente "con un escalofrío en el espinazo que (como el lector ya lo habrá previsto) Teofrasto no tenía primo alguno" 36 . Es decir, en este cuento de Espinosa parece que por fin habrá un atisbo de justicia. Sin embargo, si el consecuente castigo llega, no será fruto del valor de los vivos, que por desgracia están muertos de miedo.

En el cuento corto, Réquiem por una ingenua (1985), vuelve a introducirse en la trama de una de sus creaciones criminales. En esta ocasión, el escritor cumple el papel del investigador que pretende esclarecer los extraños hechos que rodearon el suicidio en Nueva York de una joven colombiana poco agraciada, luego de ganar un viaje con gastos cubiertos en un concurso de televisión. Como en la contradictoria anécdota de Chéjov, según la cual un hombre va a un casino, gana un millón, vuelve a casa, se suicida; en el relato espinosiano la fea gana un viaje con todo pagado, viaja a la capital del mundo, se quita la vida lanzándose desde un décimo piso en Manhattan. Esa evidente paradoja, encierra, como ha señalado Piglia, un relato secreto, una historia oculta que emerge a la superficie produciendo el efecto de sorpresa. En este caso, ese segundo relato es revelado casualmente a Espinosa por el propio protagonista.

De esta manera, el suicidio de María Ignacia Recamán pronto se transforma en un crimen con todas sus letras. El anónimo hombre, en su desahogo, le pide a Espinosa en una taberna bogotana que cuente algún día la

34 Germán Espinosa, ibidem, p. 300.

35 Germán Espinosa, ibidem, p. 301.

36 Germán Espinosa, ibidem, p. 302. 
historia, pero sin averiguar nada más. Atormentado por la culpa, confiesa que sedujo a la fea con el secreto propósito de utilizarla para transportar a Estados Unidos un "panzudo broche de plata" 37 , repleto de cuantiosas esmeraldas de Muzo. Al parecer, la infortunada joven lo pierde en alguna congestionada calle capitalina y decide reemplazarlo por uno idéntico, cuidándose de no herir los nobles sentimientos de su enamorado. Por supuesto, ignora que los implacables dueños de la mercancía le cobrarán con su vida la pérdida del valioso cargamento. De acuerdo con la lógica del relato, esta segunda historia, nunca saldrá a la luz, salvo por la verdad de la ficción. En Réquiem por una ingenua todo el despliegue periodístico se enfoca, por torpeza o facilismo, en la historia del suicidio, contribuyendo con la impunidad del crimen execrable que cometen los traficantes de esmeraldas. Es la forma que tiene Espinosa, en su condición de fabulador, de recordarles a los medios de comunicación el daño que puede producir el sensacionalismo y, sobre todo, la falta de rigor investigativo.

Pero si en todos los cuentos analizados hasta aquí la presencia del crimen ha sido una constante irrefutable, no es menos cierto que en ninguno de ellos es dable apreciar la exuberancia de la anomia y la criminalidad enquistada en todos los niveles de la sociedad colombiana como en el titulado Telefonema familiar (1993). El relato es, en realidad, la última conversación por celular de una pareja de hermanos sicarios. Berta - se sabrá al final de la llamada — ha sido contratada por el Procurador General de la Nación para asesinar a su hermano Leonardo el día de su cumpleaños. A través del fraternal diálogo, que simbólicamente se desarrolla en las cercanías de la glorieta de Los Héroes, en Bogotá, el lector se entera de una retahíla de hechos siniestros.

Descubre, por ejemplo, que al padre "lo dejaron como una galleta desmigajada" 38 y sus despojos reposan en la morgue de medicina legal. Para los hermanos, la madre es la directa responsable del hecho, pero la comprenden porque "le hicieron una oferta demasiado tentadora" 39 , ante la cual ni ellos habrían retrocedido. Además, "el viejo ya tenía sus años” y la madre necesita los cien millones para satisfacer su pasión por el juego.

37 Germán Espinosa, ibidem, p. 410.

38 Germán Espinosa, ibidem, p. 405.

39 Germán Espinosa, ibidem, p. 406. 
"Es la única debilidad que tiene. Hay que consentírsela" ${ }^{0}$. Total, también se encuentra amenazada y "en cualquier momento se la bajan" 41 .

Por otra parte, a través de la risa trágica se aprecia el contubernio perverso entre los bajos fondos del hampa y el crimen de cuello blanco. El único valor que aún subsiste es el del dinero. Los delincuentes cometen toda suerte de fechorías, mientras se pasean a sus anchas por consulados, disfrutan de estupendas vacaciones en el exterior y conversan en el Palacio de Nariño sobre proyectos de ley destinados a "proteger a nuestro gremio" ${ }^{42}$. En las pocas páginas del cuento, explotan carrobombas, se trafica con explosivos y armamento para la guerrilla, los altos dignatarios ordenan atentados, retaliaciones y el argumento más frívolo basta para justificar una atrocidad.

En ese panorama de anomia social, el hecho más cruel lo constituye, sin embargo, la completa aniquilación de la familia, fundamento primordial de la sociedad. El hogar primigenio, refugio por excelencia, se ha transmutado en un nido de víboras a sueldo que se devoran unas a otras sin el menor escrúpulo. Resulta inquietante, asimismo, la imposibilidad de sus miembros de percibir la degradación que los rodea. Es decir, cuanto más agobiante es la anomia, más invisible resulta para las criaturas que la padecen.

Telefonema familiar es, de este modo, una carcajada sarcástica en la que Germán Espinosa libera considerables dosis de humor negro e ironía. La razón la expone el autor en una entrevista, al afirmar que "quizá el arma más efectiva que, desde el punto de vista literario, requiera el siglo XXI, sea el humor. Toda época de crisis pide altas cuotas de humor, incluso de sarcasmo" ${ }^{43}$. Este cuento, en el ámbito de la narrativa breve, desmiente la mayoría de los lugares comunes que la crítica suele atribuir a la obra extensa de Germán Espinosa. Sus escasas páginas no hurgan en la historia ni en remotos confines, sino que se nutren con avidez del presente nacional, con un tono humorístico, aunque profundamente trágico, que desnuda como pocas piezas literarias la anomia y el avanzado grado de descomposición social de una sociedad sumida en el crimen y la carencia absoluta

40 Germán Espinosa, ibidem, p. 406.

41 Germán Espinosa, ibidem, p. 406.

42 Germán Espinosa, ibidem, p. 407.

43 Adrián Espinosa Torres, Espinosa oral. Las 24 mejores entrevistas a Germán Espinosa, Barranquilla, Universidad del Atlántico [recopilación de entrevistas de 1970 a 1999; breve bibliografía y biografía], 2000, p. 147. 
de directrices legales y morales. Una nación que, en suma, naufraga sin esperanza, fallida en todas sus facetas, de la cual no debe esperarse nada ya, salvo su propia aniquilación.

\section{LA INTERPRETACión DEL PRESENTE}

La mayor parte de mis relatos breves transcurren en mis tiempos, o en los que eran mis tiempos en el momento de escribirlos.

Germán Espinosa

En los cuentos criminales que se han analizado cobra plena validez la reflexión del autor respecto de sus propias temáticas: "si usted repasa mis escritos, verá que mi tema recurrente es el de la sociedad como implacable basilisco que mata cuando mira" ${ }^{44}$. No obstante, es pertinente hacer dos aclaraciones. La primera: el rechazo abierto que expresó Germán Espinosa hacia la denominada narrativa de la violencia que, luego del asesinato del caudillo liberal Jorge Eliécer Gaitán, privilegiaba la denuncia política en detrimento de los valores puramente estéticos.

En Colombia, como ya lo insinué, nos hallábamos entregados a un realismo sin perfiles, sujeto al tema reiterativo de la violencia. Por aquellos años, antropólogos y sociólogos habían revelado los horrores de esa barbarie durante los períodos gubernamentales de Ospina Pérez, de Laureano Gómez y de Roberto Urdaneta Arbeláez. Ahora, se sabía de los juegos de pelota con la cabeza destroncada de liberales, de los espeluznantes "cortes de franela", de la práctica de hacer engullir su corbata a quien la usara roja (...), de la costumbre de amputar el miembro viril a dirigentes liberales y plantarlo en la boca del cadáver a modo de cigarro y de otras lindezas que han colocado a nuestro país muy por encima, en términos de crueldad, de la Alemania de Hitler. La idea era, pues, que nuestra narrativa debía ocuparse de estos asuntos con exclusión de cualesquiera otros, lo cual empezaba a hacerla monotemática y tediosa ${ }^{45}$.

44 Adrián Espinosa Torres, ibidem, p. 144.

45 Germán Espinosa, La verdad sea dicha. Mis memorias, Bogotá, Taurus, 2003, p. 173 
De este modo, frente a la literatura de la violencia partidista Espinosa opta audazmente por la literatura fantástica. De esta transgresión a lo "literaturizable" de la época, surgirían sus primeros cuentos recogidos en el libro La noche de la trapa (1965), en donde echa mano de la ciencia ficción, la manipulación biológico-genética, el mito de la Atlántida, el arca de la alianza y el tiempo cíclico, entre otras opciones. En lo sucesivo, esa actitud transgresora sería la constante frente a la tradición literaria colombiana. Al punto de exclamar que "a mí lo que los novelistas colombianos hayan hecho, hagan o vayan a hacer me tiene sin cuidado. No soy, en puridad, un escritor colombiano, sino ante todo caribeño y, por tanto, universal" 46 . Así, al localismo panfletario, Germán Espinosa opondría un cosmopolitismo sin reservas; a las premuras del presente, la poética de la historia; a la resonancia testimonial, el predominio de la estética. Actitud que, a no dudarlo, habría de resultar en extremo insolente, escapista y sin duda reaccionaria para ciertos sectores dominantes del campo literario colombiano, rabiosamente comprometidos con el realismo. No hay que olvidar que ni siquiera el enorme prestigio internacional de un escritor de izquierda como García Márquez lo libró de tener alguna vez que dar explicaciones sobre los compromisos revolucionarios del escritor de ficciones.

La segunda aclaración tiene que ver con lo siguiente: Espinosa es el autor de un considerable número de novelas que han recibido por parte de la crítica especializada el calificativo de "históricas" ${ }^{\text {"7 }}$; sin embargo, esta dimensión no es la más significativa en el contexto de su narrativa breve. Por supuesto, hay algunos cuentos que bien podrían ser considerados históricos. Pero en ellos, el autor desconfía más que nunca de la pertinencia y precisión de este apelativo, que esconde más de una paradoja. El escritor cartagenero sabe muy bien que toda reflexión sobre el pasado, así sea el más remoto, no constituye cosa distinta que un intento laborioso por comprender la oscura maraña del presente. El pasado, por así decirlo, es apenas un artilugio del que se vale el escritor de ficciones históricas para intentar develar el rostro huidizo de su contemporaneidad. Porque, según sus propias palabras, “a cualquier lector, hablándole del pasado, es más fácil desmontarle sus pre-

46 Adrián Espinosa Torres, op. cit., p. 42.

47 Dentro de las novelas históricas de Germán Espinosa pueden citarse: Los cortejos del diablo (1970), La tejedora de coronas (1982), El signo del pez (1987), Sinfonía desde el Nuevo Mundo (1990) y Los ojos del Basilisco (1992). 
venciones y transmitirle lo que deseamos acerca del presente" ${ }^{48}$. Y añade:

Cierto público no comprende, según he logrado vislumbrarlo, el porqué un escritor se separa de su tiempo para explorar en épocas distantes: ignora que es más fácil criticar, ironizar, satirizar lo actual remitiendo al lector a tiempos lejanos, para así desmontar su guardia. Ignora, además, las ventajas que puede aportar, cuando se trata de reflexionar sobre el destino humano, la perspectiva histórica ${ }^{49}$.

En resumen, aunque Germán Espinosa escribió solo unos pocos cuentos históricos, o, como él prefiere llamarlos, "arqueológicos", en todas sus narraciones existe una búsqueda común, una pesquisa inquisitiva acerca de ese conjunto de causas y efectos de las que ha surgido, no sin una buena dosis de azar, el colombiano moderno. La cuestión de fondo, con frecuencia se olvida, no es si el autor ubica la peripecia de sus creaciones en los orígenes del cristianismo, en la Cartagena de la Inquisición y los asedios piráticos, en la Europa del Iluminismo, en las guerras independentistas latinoamericanas, en la Bogotá brumosa del siglo XIX o en el palenque épico de un monarca cimarrón, como en el bello relato Orika de los palenques (1991). Lo que realmente sustenta el recurso de la historia es, sin la menor duda, una legítima preocupación por los orígenes, el sentido y las implicaciones de la anomia social en el presente. La ruptura insuperable de Germán Espinosa, palpable en la totalidad de los cuentos criminales analizados en este artículo, trasciende incluso sus profundas desavenencias con el catolicismo, ubicándose en la esfera de la concepción política e ideológica a partir de la cual se ha levantado la "nación" colombiana.

De este modo, es posible concluir que el erotismo de sus cuentos transgrede la moral católica y controvierte los procesos históricos de secularización y laicización que caracterizan a las sociedades hispánicas y obstruyen una experiencia plena de la modernidad. Se aprecia, así, una dimensión política del erotismo como cuestionamiento tanto del ordenamiento del Estado como de las tentativas de laicización de una sociedad no secularizada. A partir del erotismo se confronta la disputa teológicopolítica sobre la que se estructura la nación colombiana.

48 Germán Espinosa, Ensayos completos, Medellín, Universidad Eafit, 2002, p. 59.

49 Germán Espinosa, ibidem, p. 65. 
El erotismo en los cuentos de Germán Espinosa es un ejercicio de reflexión política; de liberación del individuo; de superación de los prejuicios, los frenos y los preceptos de la religión católica. Un ejercicio que constituye, además, un intento por recuperar el proyecto político de la modernidad. La conexión del erotismo y la política problematiza la realidad social colombiana, con todas sus contradicciones, sujeciones e injusticias.

La evolución de esta propuesta del cartagenero evidencia la transgresión de los preceptos de la Iglesia católica a partir de las complejas relaciones que establece el erotismo con el matrimonio, el deseo y las perversiones. La transgresión eclesial cuestiona los fundamentos de la nación católica colombiana en la medida que el erotismo pone en solfa los sistemas de ideas y conductas que definen la cultura que se halla bajo la protección del Estado. Vale aclarar que por nación se entiende la identificación de un grupo humano a unos ideales, una historia y una cultura. Desde esta perspectiva, la nación es una conciencia de identidad; y el estado, la expresión política, territorial e institucional de ese conjunto de ideales que la definen. Es decir, una organización que concentra, administra y difunde los recursos que sustentan la cultura de la nación.

Lo que se ha llamado aquí la "nación católica colombiana" supone, entonces, una categoría social anacrónica y excluyente en donde las convicciones, derechos y deberes de sus miembros han sido en buena medida definidos por una religión que invade el ámbito público y convierte en ley asuntos de la vida privada, las creencias personales y la fe. De este modo, se le impone al Estado la transformación del pecado en delito y la protección de una falsa cultura nacional.

Por esta razón, cuando el erotismo transgrede el matrimonio, cuestiona asimismo uno de los pilares fundamentales de la nación católica, pues a lo largo de la historia pocas instituciones han encarnado mejor los vínculos entre el poder político, económico y eclesiástico. En la nación católica el matrimonio es un vínculo sagrado e indisoluble. Transgredirlo es, por tanto, cuestionar una de las instituciones más influyentes desde las laderas social, cultural y, como digo, política y económica.

Los cuentos de Germán Espinosa muestran, sin embargo, todas las formas en que la nación católica condena el erotismo. Por ello en general se lo percibe como desviación, desacato o perversión; y no como la natural atracción sexual de unos personajes que pretenden, simplemente, guiarse 
por los mandatos de la pasión. El erotismo supone también un deseo de otredad que contraviene las ideas coloniales de limpieza de sangre y cuestiona tanto a la España colonizadora como a la nación católica colombiana, en donde la élite construyó la creencia de una nacionalidad blanca de piel y europea de cultura. Así, el deseo erótico del Otro que plantean sus relatos transgrede la política de segregación de la nación católica.

El erotismo, en tanto que deseo de alcanzar al Otro en su intimidad, se convierte en una forma de abolir la aversión hacia lo distinto; de superar las exclusiones; de transgredir la moral y el "bien social" de una nación empeñada en reprimir los impulsos y el deseo. Esto explica las relaciones que entablan el erotismo con lo demoníaco, lo vampírico, las perversiones, la homosexualidad, el incesto, el bestialismo, la pedofilia, el exhibicionismo. Porque cuestionan la cultura oficial y muestran lo que la nación católica reprime y esconde.

Finalmente, en lo que respecta a este asunto, se puede concluir que la variedad temática de los cuentos de Germán Espinosa es relativa; se refiere, sobre todo, a la historia superficial ${ }^{50}$, la que se muestra en un primer plano. Los temas profundos son pocos y corresponden a obsesiones tales como la ausencia de erotismo en el matrimonio, el deseo entre opresores y oprimidos y la exuberancia erótica de las perversiones. A su vez, todo lo anterior tiene como finalidad la transgresión de los preceptos eclesiásticos y el cuestionamiento de los fundamentos históricos, culturales y políticos de la nación católica que pervive en Colombia. En este sentido, también vale concluir que el cosmopolitismo de Germán Espinosa, por lo menos en sus cuentos eróticos, es igualmente relativo, pues aunque las historias de la superficie se remonten a otros espacios, los temas de la segunda historia siempre están en Colombia, Hispanoamérica o el mundo hispánico. Algo similar puede decirse del componente histórico en su relación con el erotismo: pertenece a la superficie, a la primera historia; la preocupación de fondo siempre es una problemática del presente, que, por supuesto, tiene su origen en el pasado. No debe olvidarse, por último, que las naciones hacen al hombre ${ }^{51}$, de manera que criticar al hombre en su más desnuda intimidad implica, de algún modo, cuestionar las más altas esferas de la nación que lo ha forjado.

50 Véase Ricardo Piglia, «Tesis sobre el cuento», Formas breves, Barcelona, Anagrama, 2000.

51 Ernest Gellner, Naciones y nacionalismo, Madrid, Alianza, 2001. 